\title{
6. ISSUES IN CONTEMPORARY CUSTOMARY LAW: WOMEN AND THE LAW*
}

By: Jean G. Zorn

\section{KEY TERMS AND PHRASES}

\section{Discourse}

A conversation or dialogue, usually of a formal kind or in a formal setting.

\section{Dualism}

A condition in which a single entity is made up of two, sometimes conflicting, parts.

\section{Ultra vires}

A Latin phrase meaning an action that ought not to be taken because it is beyond one's power or authority, most often used in reference to government officials or company directors.

* The list of people who deserve thanks for their contributions to this chapter includes Bruce Ottley, Pamela Goldberg, Jennifer Corrin Care, Christine Stewart, Tess Newton Cain, Heather McCrae and Imrana Jalal. Some of you have actually read drafts of the chapter; every one of you has written or said things that made me think - and think again. Thanks to you all. And to the women of CUNY School of Law, who have taught me the value of a woman's approach to legal issues. And, especially, to Steve, Heather and Christopher. 
Many people argue that the law does not discriminate against women. Certainly, many laws have been changed in their written form so that they seem genderneutral, seeming to treat men and women equally. However, the legislation may have bad effects on women because women are not socially and economically equal to men. The law is produced by social, economic and political forces. It does not of itself make women unequal, but it does influence their situation. Patriarchal interpretations of written and unwritten laws combine with local social, cultural and political forces to keep the status of women inferior to that of men. ${ }^{1}$

\section{INTRODUCTION}

One of the criticisms of custom frequently heard these days is that it discriminates against women. ${ }^{2}$ Many of the critics believe that customary gender discrimination will end whenever women can get their cases into the formal courts, where judges will use the constitutions, statutes and the common law to defeat custom. ${ }^{3}$ Imrana Jalal has provided us with an excellent definition of gender discrimination:

Discrimination means treating people in different ways, depending on their sex, race, religion, political opinions, creed, sexual preference and so on. We may discriminate against a particular group of people, just as we may discriminate in favour of that particular group of people. Here we are concerned with sex discrimination. This is often called "gender discrimination" because it focuses on whether a person is male or female. ${ }^{4}$

Jalal differentiates between two kinds of gender discrimination - direct and indirect. She defines direct discrimination first:

Discrimination takes many forms, both direct and indirect. In law, direct discrimination against a woman means that something happens to a woman because she is a woman and not because she is an individual. The discrimination may be based on a particular characteristic applying generally to women (for example, being able to have babies) or it may be based on a particular characteristic that people may think women have (for example, being "emotional"). Direct legal discrimination may be obvious in the legislation or legal practices specifically permitting certain rights to men but not to women. ${ }^{5}$

When people say that custom discriminates against women, it is usually direct discrimination that they have in mind. Polygamy is often cited as an example of direct discrimination because in most societies that practice polygamy men are allowed to have several wives but women are not permitted more than one husband. ${ }^{6}$ Brideprice has also been criticised as an example of gender discrimination, ${ }^{7}$ as has the customary political process in that it tends to place women in an inferior position and to shut them out of public discourse. ${ }^{8}$

It is the thesis of this chapter that whether or not indigenous cultures are discriminatory their critics are wrong - or, at least, have been wrong up to now — in presuming that the state courts will redress the balance. To the extent that gender discrimination does 
exist under customary law, the rules and agencies of state law do little, or nothing, to correct it. State law fails to address customary examples of direct sex discrimination because, in Jalal's phrase, the instrumentalities of state law are 'indirect discrimination'. She notes that indirect discrimination can occur in three ways:

[1] Most legislation is written in gender-neutral form. It may seem not to favour men over women, but it indirectly discriminates against women, because the courts and law agencies that apply, interpret or enforce the written laws do not consider the disadvantages of women.

[2] Indirect discrimination occurs also when social and cultural attitudes cause officers of the courts, law enforcement agencies and associated agencies to interpret laws and procedures in ways that discriminate against women.

[3] The law may also be indirectly discriminatory where it fails to correct discrimination. Here, discrimination occurs not because the law does something, or does it badly, but because it omits to correct something. ${ }^{9}$

We will see examples of all three kinds of indirect discrimination in the cases to be discussed in this chapter.

In recent years, a number of instances have arisen in which customary law has discriminated against women. For example, many people in Vanuatu, especially in the Port Vila expatriate community, were shocked when four custom chiefs forced a woman to return from Port Vila to her home in Tanna because she refused to be reunited with the husband who had beaten her. ${ }^{10}$ Another example of customary discrimination against women had arisen a few years earlier in Solomon Islands, when village men refused to enter a voting booth on the grounds that its prior use by women contaminated it. ${ }^{11}$ In yet a third incident, which occurred in Papua New Guinea, a man who had killed a young girl promised to give his own daughter to the girl's parents in compensation for her death. ${ }^{12}$

All three of these incidents prompted much discussion in their respective countries and most people probably assumed that the state courts would deal with all three by voiding the relevant customary norms since they conflicted with state laws prohibiting sex discrimination. As the following discussion demonstrates, however, those expectations were proven wrong. In each instance, the case was decided on entirely other grounds. The Courts barely noted the existence of discrimination and certainly did not base their decisions on it. As such, the decisions are examples of Jalal's third definition of indirect discrimination: failures by officers of the law to correct discrimination. As the following discussion will demonstrate, the cases provide us with examples of Jalal's other forms of indirect gender discrimination as well.

\section{WOMEN AND THE POWERS OF CHIEFS}

In Vanuatu, in 1993, four "very important chiefs"13 from the southern part of Tanna held a meeting in Port Vila in an attempt to resolve the problems that had caused their kinswoman Marie Kota to leave her husband Walter. ${ }^{14}$ Marie and Walter were 
from Tanna, both subjects of the Tanna chiefs but, like many other rural villagers, they had been drawn to the capital city and had been living there for a while. A number of other Tannese, mostly friends and kin of the couple, attended the meeting. Walter was happy to attend. Marie did not want to but the chiefs sent two officers from the Vanuatu Police to her house to compel her attendance.

At the meeting the Chiefs and a number of other people suggested that Marie and her husband should get back together. Marie said that she did not wish to go back to her husband, as he had beaten her, and that she wanted a divorce. The meeting was then adjourned for 15 minutes, so that she could decide whether she really wanted the divorce or not. After that period, she said that she did want the divorce, and then it was the Chief Andrew who announced the decision of the Chiefs, that she must go back to Tanna. This decision appears to have been a consensual decision made by all the chiefs present. ${ }^{15}$

Marie told the chiefs she did not want to go back to Tanna so men were sent with her to her home, while she packed, and then to the wharf where she was put aboard a boat bound for Tanna. ${ }^{16}$ She cried all the way. She thought about jumping off the boat before it left Port Vila harbour, but was sure that, if she did, the men would find her, beat her and put her on the boat again. With help from the Vanuatu Association of Women against Violence against Women she returned to Port Vila the following week and, a few weeks later, filed a criminal complaint. ${ }^{17}$

Walter Kota, the chiefs and the other participants in the meeting were charged, some with kidnapping, some with inciting to kidnap. ${ }^{18}$ The Supreme Court had little trouble, on these facts, finding several of them guilty. Their major defence seems to have been that they did not use force but the Court noted that a conviction for kidnapping does not require the use of force. It requires merely that force be threatened ${ }^{19}$ and the Court had no trouble deducing from Marie Kota's testimony that threats had occurred:

I believe the Complainant when she said that she was crying, and that she was fearful [as] to what would happen to her, she believes that the situation she was in was such that if she had jumped off the vessel, she would have been beaten up and put back on it, and that if the ship had left the wharf and she had swam to shore, she would have been beaten. ${ }^{20}$

The defendants also raised the defence of mistake of fact. ${ }^{21}$ The Supreme Court was not sure what the defendants meant by this, as there did not seem to be any facts that they had misunderstood. The Court concluded that the defendants must be arguing that they had mistakenly believed that custom controlled the matter and that they would not be held liable under state law for actions governed by Tanna custom. The Court held there was no mistake of fact, stating: "If anything there was a mistake of law and the effective custom, but not facts". ${ }^{22}$

The judgment could have stopped there. No more was needed to dismiss the defendants' arguments, but the Court went on to discuss the role that custom had played in the matter - and the role that custom should play. One must ask why the 
Court did this, knowing, when it did so, that its pronouncements on custom were, at best, dicta. The judge, Downing J., an expatriate, was very upset at what the chiefs had done, and particularly upset that they had invoked custom to support their actions. ${ }^{23}$ And there are suggestions in the decision that this was not the only example of chiefs overstepping the legal bounds of their role. ${ }^{24}$ It may be that the Court took advantage of this case to lay down general rules for chiefly behaviour. That would explain the Court's insistence that the case did not raise a conflict between custom and the laws introduced by the colonisers, but between custom and the laws enacted by the defendants' own Parliament and people..$^{25}$

Although custom is part of the law of Vanuatu it is secondary to the Constitution and statutory law and therefore cannot be invoked to excuse actions that are in conflict with the Constitution or with statutes. ${ }^{26}$ In this case, the Court found that the chiefs' actions violated several different constitutional and statutory provisions. In forcing Marie Kota to go back to Tanna, the chiefs had violated her constitutional rights to liberty and to freedom of movement, as well as her statutory right to be free from coercion. ${ }^{27}$ Their behaviour also violated Marie Kota's right to equal treatment:

Article 5 of the Constitution makes it quite clear that men are to be treated the same as women, and women are to be treated the same as men. All people in Vanuatu are equal and whilst the Custom may have been that women were to be treated or could be treated as property, and could be directed to do things by men, whether those men be their husbands or chiefs, they cannot be discriminated against under the Constitution. ${ }^{28}$

Gender equality is one of the Court's major concerns, one of the primary reasons for the lengthy discussion of custom that concludes the judgment. But it is not the Court's only concern about custom and the behaviour of the chiefs. It may not even be the Court's primary concern.

The Court is also very much concerned about the chiefs' attempt to give themselves greater powers than they actually have in a parliamentary system of government:

...the Chiefs must realise that any powers they wish to exercise in Custom is subject to the Constitution of the Republic of Vanuatu, and also subject to the Statutory Law of Vanuatu. ${ }^{29}$

The Court is speaking here in particular about the chiefs' use of the police to compel Marie Kota to attend the meeting. The Court is so upset about this abuse of police authority that it mentions the police twice. The subject comes up first when the Court is describing the facts of the case. At that point, the Court criticises only the police themselves:

The police were consulted at the Police Station, and 2 police in a police truck... went to the house where Marie Kota was living and forced Marie to go to the meeting. I find it most astonishing and abhorrent that Vanuatu Police had anything to do with this matter... The Vanuatu Police had no authority in the legislation of this country to act as they did in this case, to bully and force a person 
to attend a meeting, and I propose to take this matter up to the Chief Commissioner of the Police. ${ }^{30}$

The Court brings up the topic a second time and this time focuses on the role of the chiefs in telling the police what to do:

...it is most unfortunate that the meeting was called in the circumstances in which it was called. It is also extraordinary as I have said, that the police were used to bully the Complainant, and this has risen again from the fundamental misunderstanding of the constitutional rights by the Chiefs, together with those around the Chiefs, whether they be assistants or members of committees of the community. ${ }^{31}$

Like everyone else in Vanuatu, the Court said, chiefs must learn to abide by the Constitution. It did bother the Court that the chiefs discriminated against Marie Kota. But the method they used to discriminate bothered the Court more. The chiefs assumed they had the power to command the nation's police - and the police agreed. It was the chiefs' assumption of the powers of modern government that most upset the Court. ${ }^{32}$

For centuries, chiefs were the supreme leaders of many of the traditional societies of the Pacific. The colonial authorities usurped much of their power, subsumed their chiefdoms into larger political entities, and changed many of the norms under which the chiefs had governed. ${ }^{33}$ At independence a number of Pacific island nations attempted to create a new balance, making a place for chiefs in the constitutional scheme of government. But the role created for the chiefs tends to be small and very different from the authority they enjoyed prior to the colonial period.

In Vanuatu, for example, Chapter 5 of the Constitution establishes a National Council of Chiefs composed of custom chiefs elected by their peers, but the Council is not a true legislative body. Its powers are limited to discussion, recommendation and consultation about matters relating to custom. ${ }^{34}$ Moreover, the constitutional provisions are merely permissive. Nothing in the Constitution requires the Council to hold discussions or make recommendations, nor, except in relation to land laws, does it require Parliament to consult with the Council. When the Council does choose to make recommendations, the Constitution does not require Parliament to follow them. Indeed, except in relation to land, the Constitution does not mention Parliament in relation to the Council. The Constitution does not specify which governmental body the Council is supposed to make recommendations to.

Despite the limitations on their powers at the national level, chiefs continue to play an important role in the political life of Pacific villages. No village is likely to do anything as a corporate body or community group without the chiefs' leadership or approval. Chiefs still maintain a measure of control over the allocation of the clan's customary land. And, as in Marie Kota's case, villagers still expect their chiefs to chair village meetings, to resolve disputes between villagers, and to punish villagers who offend against the social order. ${ }^{35}$ 
It can be said that in Vanuatu — as in many other Pacific nations - two separate but occasionally interlinking spheres of government have developed. There is the postcolonial sector, characterised by the practices, and to some extent the ideologies, of democracy, to which people belong according to the rules of citizenship and nationality. And there is also the traditional sector, characterised by chiefly (or 'big man') rule, by reciprocity and exchange, to which people belong according to kinship. Some people in Vanuatu live in only one of these worlds, either the postcolonial or the village sphere. Most people, however, have to find a way to function in both worlds.

To an expatriate judge - perhaps to anyone trained in the parliamentary system of government or the common law system of law; certainly to anyone who lives primarily, if not wholly, in the post-colonial sphere - the distinctions between the post-colonial and traditional systems probably seem too obvious even to need explaining. To their way of thinking, except as granted by the Constitution, chiefly power is confined to the traditional sphere; to the extent that chiefs have any authority at all in the post-colonial sphere, it is limited to that given by the Constitution; and, since the Constitution gives to chiefs no authority over the police, it is ultra vires for chiefs to try to exercise power over the police. Similarly, to the minds of those living in the post-colonial sector, the police are purely a product of that sector, ought to take orders only from officials within that sector, and have no business doing what someone in the traditional sector has told them to do.

However, to chiefs and other villagers, and to persons (members of the police force, for example) who are attempting to negotiate a life that spans both spheres, the distinctions may appear very different. Chiefs are used to commanding their men to do their bidding, especially when the chiefs think they are doing right. Chiefs see themselves as political leaders, equal, if not superior to, the members of parliament from their districts. Villagers have the same dualistic perspective and most police officers come from, still live in, villages. So it is not surprising for chiefs to assume that, on a visit to the capital city, they can ask those who enforce the rules, at the behest of political leaders, to act for them in the same capacity. Nor is it surprising that the police would do so.

Out of the dualism that characterises Vanuatu politics today, something new will evolve. It is from crossovers of this sort that a new political system will gradually emerge. The expatriate judge who decided Public Prosecutor v Kota believed that he knew what the future should be. Chiefs, he believed, should stay in their sphere, police in theirs. But he will leave, and Vanuatu will go on. Ni-Vanuatu chiefs, police, villagers, town-dwellers, judges, magistrates, lawyers, members of parliament, husbands and wives will all have a say, whether or not they intend to, in the political system that is to come. We cannot know today precisely what it will be like, but we can make some guesses. Will it treat women with more respect and less discrimination? That is greatly to be hoped. Will it find creative and functional ways to merge the post-colonial and the traditional, introduced law and custom? That, too, is to be hoped - and, I think, expected. 


\section{WOMEN AND THE VOTE}

In Solomon Islands in 1986 twenty-two men came to a polling station intending to vote in an election for the Malaita Provincial Assembly but left without voting. ${ }^{36}$ Since the successful candidate won by only three votes it is evident that the votes of the twenty-two might have changed the outcome of the election. The men did not vote because:

Men who follow the old religion believe they will be ritually contaminated if they enter a room that contains a menstruating woman or which has contained a menstruating woman that same day. The presiding officer refused to make special arrangements for these men such as allowing them to vote first; bringing the ballot box outside the voting compartment; or voting on their behalf. ${ }^{37}$

The High Court was asked to overturn the election on the grounds that "the voting was so conducted by the Returning and Presiding Officers as to be discriminatory against" these twenty-two voters. ${ }^{38}$ The Court let the results of the election stand. In doing so, it noted that if the election officials had made any special provisions for the men so that they could vote - allowing them to vote first, for example, or building them a separate polling booth - that might have constituted discrimination against women..$^{39}$ But, despite the fact that the Court said this, women's right to equal treatment under the law was not the legal basis on which the decision turned, nor was gender equality the value that the Court seemed most interested in protecting.

The legal argument that swayed the Court was a narrowly literal reading of the applicable regulations which provide that voting is to take place in a "screened compartment in the polling station" . ${ }^{40}$ And, the Court held, "it was no part of the duty of the presiding officer to make any alternative arrangement". ${ }^{41}$ The regulations did provide an exception to the requirement that voters cast their ballots in a closed room, but the exception applied only to voters unable to cast their votes "by reason of blindness or other physical disability." "I2 "In the instant case", the Court pointed out, "the twenty-two pagan voters had no physical disability whatever and there was nothing to prevent them from voting other than their fear and respect for their custom". ${ }^{43}$

If the Court had wanted to, it could have interpreted the regulations more broadly, in a way that would have allowed the twenty-two disenfranchised men to vote. For example, the Court could have looked to the purpose of the regulation ${ }^{44}$ which, so the Court itself finds, is to protect the secrecy of the voter's choice..$^{45}$ The Court could have pointed out that this purpose is intended to benefit voters and could then have held that the persons that a regulation is intended to benefit can waive the benefit, especially if they do not experience it as benefiting them. ${ }^{46}$

Counsel for the election officials gave the Court another argument that the Court might have used to avoid the strict application of the regulation. Counsel pointed out that government was currently considering new regulations that "would expressly enable anyone prohibited by any customary rule from entering the polling station... to be able to require the presiding officer to cast his vote for him". ${ }^{47}$ The Court 
turned down the opportunity to fashion relief for the voters from this for two reasons. First, the Court said that the revised regulation was not yet in force and "I can only look at the law as it stands at the present time" ${ }^{48}$ Secondly, the Court questioned whether the men's distaste for entering the voting booth after women had been in it actually was "a point of customary law" - or was it, the Court asks, "merely a religious tenet or belief"? ? $^{9}$

If the men were motivated solely by religion and not by customary rule, the Court seemed to be holding, then their actions would not be protected by the regulation, even if the revised version were in force, because it refers to "customary rules" and not to "religious tenets or beliefs". No one seems to have brought to the Court's attention s 5(1)(f) of the Constitution (Solomon Islands), which guarantees freedom of worship and belief. We cannot know, once the new regulation came into force, whether a Court might hold that it could not stand because it violated this Constitutional guarantee. ${ }^{50}$

We must wonder, because the Court's distaste for the religion practised by the twenty-two men seems to have been the core value driving the Court to the decision it reached on the law. The Court mentioned the fact that the men's actions discriminated against women only once, and only in the course of quoting the arguments made by counsel for the election officials. ${ }^{51}$ The Court dwelt, however, on the fact that the men were, in its words, "non-christian". ${ }^{22}$ They are, the Court noted more than once, "pagan" ${ }^{33}$ They practise "the old religion" $"{ }_{54}$ which has rules that out of "fear" they will not disobey. ${ }^{55}$ These are not words that a disinterested party would use to describe a religion other than her own. These are the words and concepts Christianity uses to impugn non-Christian religions. The Court's choice of words is evidence that the Court's dislike for the traditional religious beliefs of Solomon Islanders had little to do with their attitudes toward women and everything to do with the fact that they dared to be non-Christian.

The case was resolved (at least until the new regulations were in force) in favour of women, but the reasons for that resolution did not involve women's equality. It involved the inferiority, in the minds of a Christian judge, of all religions except Christianity. This is not an unusual viewpoint to find in Melanesia. Although the Pacific was colonised primarily for economic and political reasons, the colonisers often justified their brutal mission on the grounds that they were bringing the benefits of civilisation, law and religion in particular, to the savage pagans of the Pacific. ${ }^{56}$ But if the colonisers were to convince themselves, let alone Pacific islanders, of the truth of this justification, they had to remain convinced at any cost, that Christianity was superior in all respects to the homegrown religions of the Pacific. ${ }^{57}$ It is sad, but not surprising, therefore, to find that contemporary carriers of the colonial banner still believe it imperative to trumpet the merits of the Christian religion at the expense of other belief systems. 


\section{WOMEN AND COMPENSATION}

In a 1991 case in Papua New Guinea a defendant pleaded guilty to the unlawful killing of his sister-in-law. ${ }^{58}$ At the sentencing hearing the defendant argued that he should receive a light sentence because he would have to comply with the "customary obligation... to hand over one of his daughters for the deceased's family" to compensate them for the loss of their daughter. ${ }^{59}$ As an example of gender discrimination the case is problematic. The defendant's willingness to give away a daughter seemed to the expatriate and urban communities, who read about the case over their morning newspapers, to mean that he and the customary rules he was following were treating a young woman with no more regard than they would treat a pig or a shell or any other kind of property that is normally given as part of a compensation agreement. However, the Court did not treat the matter as genderrelated. Instead, the Court seemed to presume that the custom might apply to children of either sex. As such, the Court held that the custom was wrongful, not because it discriminated against women but because, to the Court's mind, it failed to care properly for children.

The Court was probably correct in finding that the custom of giving children in compensation applies to boys as well as to girls. ${ }^{60}$ Nevertheless, the Court's analysis of the issues in the case would have benefited from a gendered approach. It is particularly ironic that the Court did not do so in this case because the judge, Doherty J., is a woman. Feminist jurisprudence teaches us to pay attention to the particularities of litigants' stories, to the context of their cases and to the narrative that gave rise to the issues. ${ }^{61} \mathrm{Had}$ the Court done this, it might have found a way to resolve the matter that affirmed the dignity and selfhood of the individuals involved without denying the integrity and value of their customs.

The Court, however, approached the case as if every instance in which a child is given in compensation to grieving parents is the same. There is nothing in the decision about the particular facts of this case, about how the defendant felt at giving up his child, about how the foster parents would treat the child. The Court held that the custom violated both the Customs Recognition Act [Cap 19] (PNG) and the Constitution (PNG). It would violate s 3 of the Customs Recognition Act because, to the Court's mind, it would be:

contrary to the welfare of [a] child under sixteen years... and... contrary to the public interest to... reduce sentence where it was shown that a child or young person or even an adult was handed over by one group of people to another family or group in payment of obligations of some member of the child's clan or customary group. ${ }^{62}$

But, is it necessarily contrary to the welfare of a child to give her (or him) to grieving parents who will welcome a child to replace their lost daughter or son? The judge's words suggest that she believes it is never in 'the welfare of a child' to use the child in payment of an obligation. But, if the welfare of the child is at issue, ought not the inquiry to be into whether the child has been placed in a good and proper home rather than into the motivations that prompted the placement? 
The Court's second reason for refusing to recognise and apply the custom was that the custom violated s 253 of the Constitution (PNG), which prohibits "slavery and the slave trade in all its forms, and all similar institutions and practices". ${ }^{63}$ The Court reasoned that the custom of giving a child to replace the child one has killed is a practice similar to slavery:

I am unable to trace any case law in our jurisdiction on the interpretation of this section [of the Constitution] and the word 'slavery' is not defined in our legislation... [but]... The International Convention on the Abolition of Slavery and the Slave Trade... refers to slavery as "the status or condition of a person over whom all or any other powers attaching to the right of ownership are exercised." ${ }^{64}$

Using this definition, the Court found that the defendant's obligation to part with his daughter was, in the words of s 253 of the Constitution, an institution or practice similar to slavery in two ways. First, the child had no say in the transaction. Secondondly, the defendant was "handing over... a child, or an adult, to another family or group in payment or recompense for the misdeeds of a third person". ${ }^{65}$

Despite the Court's care to find a definition of slavery, whether a practice is like slavery may be in the eye of the beholder. If it is slavery to place a child with a family without the child's consent then almost all foster placements and adoptions, wherever they happen, are practices similar to slavery, because the consent of the child is seldom sought. And if it is wrong to give a child in compensation for one that has been lost, then many common, and quite legal, practices are wrong. That reasoning would make it wrong for a poor woman to give up her child so that wealthier parents can raise the child. It would make it wrong for couples to pay surrogate mothers, to invest in fertility clinics or otherwise to compensate anyone for helping them to adopt or give birth to a child. ${ }^{66}$ All these practices involve, either directly or indirectly, payment in connection with obtaining a child, the practice that seems to most anger the Court in this case.

Whether the gift of the child was in the child's welfare, whether it forced the child into slavery, depends upon the particular facts of the story. If the adopting family were intending actually to treat her as a daughter then it might not be against her welfare. It might not be slavery. If the child and her new family were from the same village the child's circumstances might not even change appreciably, despite the normative change in parents. In most Pacific villages children move freely around the village, cared for by every adult. ${ }^{67}$ If, on the other hand, the adopting family were forever to hold her father's crime against the child, if she were made to work ceaselessly to pay his debt, then it would not be in her welfare. It would be slavery. We cannot decide this, however, without knowing more of the story behind the case.

In the end, the Court did not even decide the case on these grounds. Instead, the Court decided the case on the basis of evidentiary rules, holding that the existence and application of the custom had not been proved, and although "customary compliance is a matter that can be considered in mitigation" of sentence, "customs must be proved as a fact, that is by sworn evidence or affidavit evidence" ${ }^{68}$ The Court was even aware that the custom did indeed exist, but nonetheless refused to 
recognise or apply it in the absence of sworn evidence put into the record by the defendant's counsel:

I am aware of this Custom in that part of the Sepik from other cases but I consider in this situation before me where a submission by Counsel only is put forward is insufficient evidence that a custom exists, what the custom exactly is and whether the defendant has complied with it. ${ }^{69}$

In choosing to decide the case on this basis the Court may here have been reacting to other cases in which counsel had failed to prove custom as the statute required.70 The Court may have been trying to send a message to counsel that courts would not apply customary law unless counsel did the work of presenting that law to them. It seems more likely, however, given the extensive dicta on the Court's view that this custom is unlawful and unconstitutional, that the Court wanted to be as certain as possible that no appeal would enable the defendant to get a mitigated sentence on account of this practice.

The people in every culture believe that they know what is in the welfare of their children. And they do. At least, they know what is in the welfare of the children of their culture. But cultures differ, and what may be in the welfare of the children of one culture is not necessarily good for the children of another culture. A child taught to honour the clan, to raise healthy pigs and to fight with bravery would do very well in the Highlands of Papua New Guinea but not so well in London. However, a child taught to find his station on the London Underground, to buy his lunch from the fish and chip shop and to conjugate Latin verbs would not survive for long in a Highlands village, no matter how well-prepared he was for English life.

In deciding State v Kule, Doherty J. seems to have confused the values, needs, interests and beliefs of Papua New Guinea culture with those of her own. In her culture, with its nuclear families and its consequent emphasis on the parent-child relationship, it might well be against the welfare of the child to be adopted for any reason other than that its adoptive parents intend to cherish it. In Papua New Guinea's villages, however, it may be less necessary for the state to put its efforts into strengthening the parentchild bond, because children are loved and cared for by every adult in their extended family or clan. In Papua New Guinea, it may well be in the best interests of this child to move from one village household to another, so long as she will be loved in both, and especially as she will know that, in doing so, she is helping to preserve her father's honour and the good relations of everyone in the village.

\section{CONCLUSIONS AND AFTERTHOUGHTS}

We have looked at three cases that might have been about custom's treatment of women, but turned out to be about other things entirely. Public Prosecutor v Kota was about the powers of chiefs in Vanuatu's dual political system. Talusui $v$ Toneewane was about religion in Solomon Islands. And The State v Joseph Kule was about the welfare of children. In at least two of the cases the judges recognised that women were being made the subjects of discrimination but in none of them did the courts see it as their job to put an end to gender discrimination. This blindness on the part 
of the state legal system, these examples of indirect discrimination, permitted the direct discrimination of customary law to continue unchecked.

The cases demonstrate the varieties of indirect discrimination that Imrana Jalal has identified..$^{71}$ The proposed regulation described in Talusui v Tone-ewane was genderneutral on its face but would have had a discriminatory impact on women, a result the Court failed to consider. In The State $v$ Joseph Kule the judge's social and cultural attitudes blinded her to the possible realities of the situation. And, in Public Prosecutor $v$ Kota the judgment did not necessarily correct the discrimination created by custom.

These cases raise a number of questions and issues about custom, state law and gender. In particular they make us realise that women are the subjects of double discrimination. They are directly discriminated against by custom - at least by custom as it operates today - and they are indirectly discriminated against by a state legal system that fails to redress the problems caused by custom. How might women's lives differ if judges recognised and redressed gender imbalances? How differently might these cases have been decided if the judges focused on gender? The decisions raise issues for the lawyers who represent women as well. The discriminatory nature of certain customary norms and practices must be carefully spelled out to the courts by counsel if we expect the courts to act in favour of women's rights to equality at all.

Finally, the cases raise questions about the treatment in the courts of custom and customary law. In each of these cases, state courts refused to recognise and apply a customary norm. And, in each case, the court did so for a different reason. In one case, the customary practice conflicted with the Court's notion of proper religious expression. In another, the customary norm was at odds with the Court's view of the separation that ought to be maintained between the chiefly and parliamentary spheres of government. In the third the Court believed that custom did not take due regard of the welfare of children.

Whether custom or the state courts is correct in each of these instances is not the most important question. The more important inquiry is why customary law and the law of courts and constitutions continue, more than a quarter-century after most Pacific nations came into being, to be so far apart. What can be done to bring them into better conjunction with one another so that citizens do not feel themselves torn between two legal systems placing conflicting duties and obligations upon them?

We who would like to do better are faced with a problem. We want to respect the integrity of the indigenous cultures of the Pacific, but we also want those cultures to act in ways that affirm the integrity and dignity of all persons. How do we accomplish both these goals? The state courts have so far failed to find the proper balance. In the cases we have discussed in this chapter, the courts have interfered with indigenous cultures without creating laws that improve the lives of women. How do we, and the courts, do better? 


\section{ENDNOTES}

1 Jalal, P.I. 1998. Law for Pacific Women: A Legal Rights Handbook. Suva: Fiji Women's Rights Movement at p15.

2 Counts, D.A. Brown, J.K. and Campbell, J.C. (eds.) 1999. To Have and to Hit: Cultural Perspectives on Wife Beating (2nd Edition). Chicago: University of Illinois Press; Toft, S. (ed.) 1985. Domestic Violence in Papua New Guinea (Monograph No. 3). Boroko: Papua New Guinea Law Reform Commission; Zorn, J.G. 1994-95. Women, Custom and State Law in Papua New Guinea. Third World Legal Studies. 1994-95: 169-205.

3 See, for example, the references collected in Counts, D.A. Brown, J.K. and Campbell, 1999. Above n 2, pp 299-301; Papua New Guinea Supreme Court. 1991. Annual Report of the Judges 1990. Port Moresby: Government Printing Office, p 7.

4 See above, $\mathrm{n} 1$ at $\mathrm{p} 16$.

5 See above, $\mathrm{n} 1$ at $\mathrm{p} 16$.

6 Kaganis, F. and Murray, C. 1991. Law, Women and the Family: The Question of Polygyny in a New South Africa. Acta Juridica 1991: 116-132; Jessep, O. 1992. The Governor General's Wives - Polygamy and the Recognition of Customary Marriage in Papua New Guinea. Australian Journal of Family Law 1992: 29-49.

7 See Zorn elsewhere in this section and the cases and articles on brideprice discussed and cited therein.

8 Gailey, C.W. 1987. Kinship to Kingship: Gender Hierarchy and State Formation in the Tongan Islands. Austin: University of Texas Press; Berndt, R.M. and Lawrence, P. (eds.) 1971. Politics in New Guinea. Nedlands, W.A.: University of Western Australia Press.

9 See above, $\mathrm{n} 1$ at $\mathrm{p} 16$.

10 The case, discussed below, is Public Prosecutor $v$ Kota, Unreported, Supreme Court of the Republic of Vanuatu, Criminal Case No. 58 of 1993, 31st August 1993.

11 That case, also discussed below, is Talusui v Tone-ewane [1986] S.I.L.R. 140. The Solomon Island Law Reports are available at many court and university libraries throughout the Pacific.

12 The State v Joseph Kule, Unreported, The National Court of Justice of Papua New Guinea, N1034 of 1991. The case is on file at the University of Papua New Guinea and the University of the South Pacific Law School libraries.

13 So they are described by the court in Public Prosecutor $v$ Kota, above n 10 at p 2.

14 Throughout Melanesia village meetings are the customary proceedings through which disputes are resolved. The meetings are usually called by one of the parties to the dispute, though sometimes friends, kinspeople or chiefs organise the meeting. Everyone in the village, everyone related to the parties, anyone with an interest in the dispute, is encouraged to attend and to speak at the meeting. Unlike a trial in a state court which follows strict rules of evidence and procedure, and at which discussion is limited to the particular issue that brought the parties to the trial, village meetings range broadly over all the issues that have arisen between the parties. The aim of the meeting is not to declare that one party has won and the other lost, but to resolve the dispute between them through compromise or consensus. To that end, chiefs or other leaders of the meeting do 
not act as judges, issuing rulings and deciding the case. Instead, they tend to act as mediators, trying to bring the parties to a conclusion that both can agree upon. A chief may state his opinion about what the parties should do. A chief may remind the parties of the values of their society. But the chief will not force an outcome. Thus, while the chiefs in this case ordered Marie to go back to Tanna, they did not order her to go back to her husband. They believed she should, they said she should, they obviously hoped that, once in Tanna, she would decide to do it. But they did not order it. They refrained from making that order, just as chiefs involved in village meetings have always refrained from making orders, because, in traditional Melanesia, there were no police to enforce the orders of chiefs. Chiefs could depend upon being obeyed only when people agreed with what the chief had said so chiefs did not go beyond what people would do. The chiefs could use their power to get Marie back to Tanna, but they did not have the power to make her stay with Walter. For further information on the village meeting as a cornerstone of customary legal procedure, see Epstein, A.L. (ed.) 1974. Contention and Dispute: Aspects of Law and Social Control in Melanesia. Canberra: Australian National University; Nader, L. and Todd, H.F. (eds.) 1978. The Disputing Process - Law in Ten Societies. New York: Columbia University Press; Adamson Hoebel, E. 1979. The Law of Primitive Man. New York: Atheneum.

15 See above, n 10 at $\mathrm{p} 2$.

16 Plane flights between Port Vila and Tanna take under an hour but they are expensive. NiVanuatu villagers are more likely to travel on one of the many small cargo and passenger boats that are a major means of commercial transportation amongst the several islands that make up the archipelago. Even though the boat trip between Port Vila and Tanna takes two days it is considerably less expensive than a plane trip. Nonetheless it is costly enough so that the average villager would not do it often.

17 The decision does not say so but she probably would not have been able to afford the fare to return without the assistance of the Association.

18 See Penal Code [Cap. 135] (Vanuatu), ss 35 (incitement) and 105(b) (kidnapping).

19 See above, $\mathrm{n} 10$ at $\mathrm{p} 4$.

20 See above, $\mathrm{n} 10$ at $\mathrm{p} 3$.

21 Penal Code [Cap 135] (Vanuatu).

22 See above, n 10 at p 4. Counsel for the defendants might also have intended to raise custom as a mitigating factor at the sentencing stage, but I doubt they did so after the court's decision on the merits.

23 The case was a subject for much discussion in the expatriate community at the time and for several years after, mostly as an example of the misogyny of custom.

24 See, for example, the Court's comment near the end of the decision: "It is up to the Parliament of this Nation to consider whether any amendments need to be made with the Constitution or other Legislation to clarify what is the role of the Chiefs" above, n 10 at p 4 .

25 See above, $\mathrm{n} 10$ at $\mathrm{p} 4$.

26 See above, n 10 at p 4 . 
27 See Constitution (Vanuatu) Art. 5(1)(b) (liberty) and Art. 5(1)(i) (freedom of movement); Penal Code [Cap 135] (Vanuatu) s 105(b).

28 See above, $\mathrm{n} 10$ at $\mathrm{p} 4$.

29 See above, $\mathrm{n} 10$ at $\mathrm{p} 4$.

30 See above, $\mathrm{n} 10$ at $\mathrm{p} 2$.

31 See above, $\mathrm{n} 10$ at $\mathrm{p} 4$.

32 To be fair, the Court is also concerned that chiefs act in ways that do not discriminate against women: "I think it is very important that if the role of the Chiefs is clarified by legislation, the fundamental rights of women in Vanuatu must be protected", above n 10 at p 4.

33 The discussion of chiefly powers in this and the following paragraphs of the text is taken from Zorn, J.G. 1994. Custom and Customary Law (Book Two). Suva: University of the South Pacific Extension.

34 The Council of Chiefs "has a general competence to discuss all matters relating to custom and tradition", may make recommendations for the preservation and promotion of niVanuatu culture and languages, and may be consulted on any matter in any bill before Parliament, particularly on bills relating to tradition and custom. See Constitution (Vanuatu), Art 29. In addition, Article 74 provides that Parliament may, after consultation with the Council of Chiefs, enact a national land law.

35 See, for example, Kaliopa v Silao, Unreported, High Court of American Samoa, Land and Title Division, 1983; Mose v Masame, [1930-49] WSLR 140; McMoore et al. v Popoali'i et al., Unreported, High Court of American Samoa, Land and Title Division, LT No. 20-88, 1989.

36 Talusui v Tone-ewane Above, $\mathrm{n} 11$.

37 See above, $\mathrm{n} 11$ at $\mathrm{p} 141$.

38 See above, $\mathrm{n} 11$ at $\mathrm{p} 141$.

39 Actually, it was counsel for the election officials who mentioned the possibly discriminatory impact of requiring women to wait until the men had voted, but the Court approved of counsel's submission, calling it a reasonable argument. See above, n 11 at p 142.

40 Local Government (Elections) Regulations (Solomon Islands), s 20(d) paraphrased in Talusui $v$ Tone-ewane above, n 11, at p 142.

41 Local Government (Elections) Regulations (Solomon Islands), s 20(d).

42 Local Government (Elections) Regulations (Solomon Islands), s 20 (g).

43 See above, $\mathrm{n} 11$ at $\mathrm{p} 142$.

44 Courts have available a variety of methods to help them interpret statutes. This court chose to look only at the 'plain meaning' of the statute - what the words, on their face, seem to say. A positivist court (a court that prefers to apply the rules as written, rather to look at the policies or purposes behind the rules) would probably insist that, in interpreting a statute, it is limited to the statute's 'plain meaning' unless that meaning is not plain. Unless, that is, the statute is itself confusing or ambiguous. Most courts today, however, will look to the purpose that the statute is intended to serve, regardless of whether there is an ambiguity on the face of the statute, because most judges today would prefer to enforce the law that was actually intended, rather than some typographical error 
that has crept into the law and made it into a mockery of itself. Courts that interpret statutes by looking to the policies and purposes they are meant to serve can find those policies and purposes in three ways - by reading the preamble or other purposive language contained in the statute, by looking to the legislative history for clues as to what Parliament intended when it enacted the bill, or by drawing the purpose from the general language and effect of the statute.

45 See above, $\mathrm{n} 11$ at $\mathrm{p} 142$.

46 The Court might have decided not to use this argument because the case was not actually brought by the disenfranchised men themselves, but by the losing candidate for elected office, who claimed he might have won had they voted for him.

47 See above, n 11 at p 143.

48 Yes, but: If it had wanted an outcome that supported the 22 non-voters, the Court could have taken the proposed change in the legislation, especially since it was close to coming into force, as a signal that government policy favoured a broad interpretation of the regulation so as not to disenfranchise voters. See above, $\mathrm{n} 11$ at $\mathrm{p} 143$.

49 See above, n 11 at $\mathrm{p} 143$.

50 The Court could hardly be unaware of the existence of Sec. 5(1)(f) of the Constitution. It is possible that the Court felt unable to use it because it had not been brought to the Court's attention by counsel. It is also possible that the Court was unwilling to use it for the reasons discussed in this chapter.

51 See above, $\mathrm{n} 11$ at $\mathrm{p} 142$.

52 See above, $\mathrm{n} 11$ at $\mathrm{p} 141$.

53 See above, $\mathrm{n} 11$ at, pl42 (three times), pl43 (once) and pl44 (once).

54 See above, $\mathrm{n} 11$ at $\mathrm{p} 141$.

55 See above, $\mathrm{n} 11$ at $\mathrm{p} 142$.

56 See Moorehead, N. 1966. The Fatal Impact: The Invasion of the South Pacific 1767-1840. London: Hamish Hamilton at pp 79-85; Howe, K.R. 1984. Where the Waves Fall: A New South Sea Islands History From First Settlement to Colonial Rule. Sydney and London: Allen \& Unwin at pp 288-318.

57 In the event, Christianity was spread so successfully that it could now be considered the new custom of the islands.

58 The State $v$ Joseph Kule. Above, n 12.

59 See above, $\mathrm{n} 12$ at $\mathrm{p} 4$.

60 Freedman, M.P. 1970. Social Organization of a Siassi Community. In Harding. T.G. and Wallace. B.J. (eds.) Cultures of the Pacific. London: Collier Macmillan. 159-179, at p 166.

61 Weisberg, D.K. (ed.) 1993. Feminist Jurisprudence: Foundations. Philadelphia: Temple University Press.

62 See above, n 12 at pp 4-5. Section 3(1)(b) of the Customs Recognition Act [Cap. 19] forbids the recognition by state courts of customs that are contrary to the best interests of a child under sixteen years, and s 3(1)(a) forbids the recognition of customs that are contrary to the public interest. For an excellent discussion of customary law as it relates to the best interests of children, see McCrae, H. 1981. Cases and Materials on Family Law- 
Part III: Custody, Maintenance, De Facto Relationships and Ex-Nuptial Children. Port Moresby: University of Papua New Guinea. At pp. 2-7 and McCrae, H. 1982. Reform of Family Law in Papua New Guinea. In Weisbrot, D. Paliwala, A. and Sawyer, A. (eds.) Law and Social Change in Papua New Guinea. Sydney: Butterworths. 127-148.

63 I do not know of a Papua New Guinean society that had a slave class. I am therefore left to wonder where this constitutional provision came from. Usually, fundamental rights provisions refer to wrongs that the government itself (or a previous government) has committed.

64 See above, n 12 at p 5.

65 See above, n 12 at p 5.

66 All of these practices have been held legal by courts in various jurisdictions. See Areen, J.K. 1999. Family Law (4th ed.) Westbury, New York: Foundation Press and Saban, C. 1999. Miracle Child: Genetic Mother, Surrogate Womb. New York: New Horizon Press.

67 Mead, M. 1930. Growing Up in New Guinea. New York: Mentor.

68 See above, n 12 at p 4, citing Henry Aisi v Malaita Hoala [1981] PNGLR 199, at p 203.

69 See above, n 12 at p 4.

70 The Customs Recognition Act, s 2(1), required custom to be proven as a fact. It has been superceded recently by the Underlying Law Act 2000, which provides that custom is law and can be found by judicial notice. So, under the new Act, the fact that the custom was notorious enough for the judge to know about it would probably have meant that the judge could not refuse to recognise it, at least not on evidentiary grounds.

71 See above, $\mathrm{n} 9$ and accompanying text. 